\title{
Seasonal and tidal influence on the variability of nitrous oxide in the Tagus estuary, Portugal
}

\author{
CÉLIA GONÇALVES ${ }^{1}$, MARIA JOSÉ BROGUEIRA ${ }^{1}$ and \\ MARIA FILOMENA CAMÕES ${ }^{2}$ \\ ${ }^{1}$ INRB/IPIMAR/UAMB, Unidade de Ambiente Marinho e Biodiversidade Av. Brasília, 1440-006, Lisbon, Portugal. \\ E-mail: cpg@ipimar.pt \\ ${ }^{2}$ FCUL/DQB, Department of Chemistry and Biochemistry, Faculty of Sciences of the University of Lisbon, C8, \\ 1749-016, Lisbon, Portugal.
}

\begin{abstract}
SUMMARY: In order to evaluate seasonal and tidal influence on the variability of dissolved nitrous oxide $\left(\mathrm{N}_{2} \mathrm{O}\right)$ in the Tagus estuary, Portugal, water sampling was carried out along the salinity gradient (May and November 2006) and during several tidal cycles (February and April 2007) at a fixed site. $\mathrm{N}_{2} \mathrm{O}$ and other relevant environmental parameters, temperature, salinity, dissolved oxygen and inorganic nitrogen forms (nitrate, nitrite and ammonium) were measured. Dissolved $\mathrm{N}_{2} \mathrm{O}$ concentrations showed strong tidal and seasonal variability, with the highest values occurring in February 2007 (13.7 nM, spring tide) and November 2006 (18.4 nM, upper estuary), apparently related to major Tagus river discharge. The existence of $\mathrm{N}_{2} \mathrm{O}$ sources was noticed in middle estuary. During spring tide, the input from external sources may be augmented by water column nitrification, making this process a contributor to the enhancement of $\mathrm{N}_{2} \mathrm{O}$ concentration in the estuary. Estimated $\mathrm{N}_{2} \mathrm{O}$ air-sea fluxes to the atmosphere reached a maximum value of $\sim 10.4 \mu \mathrm{mol} \mathrm{m} \mathrm{m}^{-2} \mathrm{~d}^{-1}$ in February 2007 during spring tide and in May 2006 in the upper and lower (left bank) estuary. Although the Tagus estuary behaves predominantly as a source of atmospheric $\mathrm{N}_{2} \mathrm{O}$, it appears to be a weaker source than other, more eutrophic estuaries.
\end{abstract}

Keywords: nitrous oxide, tidal cycles, seasonality, nitrification, air-water fluxes, Tagus estuary.

RESUMEN: INFLUENCIA ESTACIONAL Y DELASMAREASEN LA VARIABILIDADDELÓXIDONITROSO ENELESTUARIODELTAJO(PORTUGAL). - Para evaluar la influencia estacional y de las mareas en la variabilidad de óxido de nitrógeno disuelto $\left(\mathrm{N}_{2} \mathrm{O}\right)$ en el estuario del Tajo (Portugal) se han recogido muestras de agua a lo largo del gradiente de salinidad (mayo y noviembre de 2006) y durante varios ciclos de las mareas (febrero y abril 2007) en una estación fija. Han sido medidos $\mathrm{N}_{2} \mathrm{O}$ y otros parámetros relevantes del medio ambiente, temperatura, salinidad, oxígeno disuelto y las formas de nitrógeno inorgánico (nitrato, nitrito, amonio). Las concentraciones de $\mathrm{N}_{2} \mathrm{O}$ disuelto mostraron una fuerte variabilidad estacional y de las mareas, observándose los valores más altos en febrero de 2007 (13.7 nM, marea viva) y noviembre de 2006 (18.4 nM, estuario superior), aparentemente relacionados con el mayor caudal del río Tajo. La existencia de fuentes de $\mathrm{N}_{2} \mathrm{O}$ se observó en el estuario del medio. Durante la marea viva, la entrada de fuentes externas puede ser ampliada por la nitrificación en la columna de agua, haciendo que este proceso contribuya al incremento de la concentración de $\mathrm{N}_{2} \mathrm{O}$ en el estuario. Los flujos estimados de $\mathrm{N}_{2} \mathrm{O}$ a la atmósfera alcanzaron un valor máximo de $10.4 \mu \mathrm{mol} \mathrm{m}^{-2} \mathrm{~d}^{-1}$, ya sea en febrero de 2007, durante la marea viva, $\mathrm{o}$ en mayo de 2006, en el estuario superior. Aunque el estuario del Tajo se comporta principalmente como una fuente de $\mathrm{N}_{2} \mathrm{O}$ atmosférico, parece ser una fuente más débil que otros estuarios más eutróficos.

Palabras clave: óxido nitroso, ciclos de marea, variabilidad estacional, nitrificacion, flujos, estuario del Tajo.

\section{INTRODUCTION}

In the last few decades, the study of nitrous oxide $\left(\mathrm{N}_{2} \mathrm{O}\right)$ has acquired greater importance due to its role in the Earth's climate. $\mathrm{N}_{2} \mathrm{O}$ acts as a greenhouse gas, with a global warming potential per molecule more than 200 times that of carbon dioxide (IPCC, 2007). Stratospheric $\mathrm{N}_{2} \mathrm{O}$ is the major source of $\mathrm{NO}$ radicals, which are involved in the depletion of the ozone layer in the stratosphere (Cicerone, 1987). Despite the substantial 

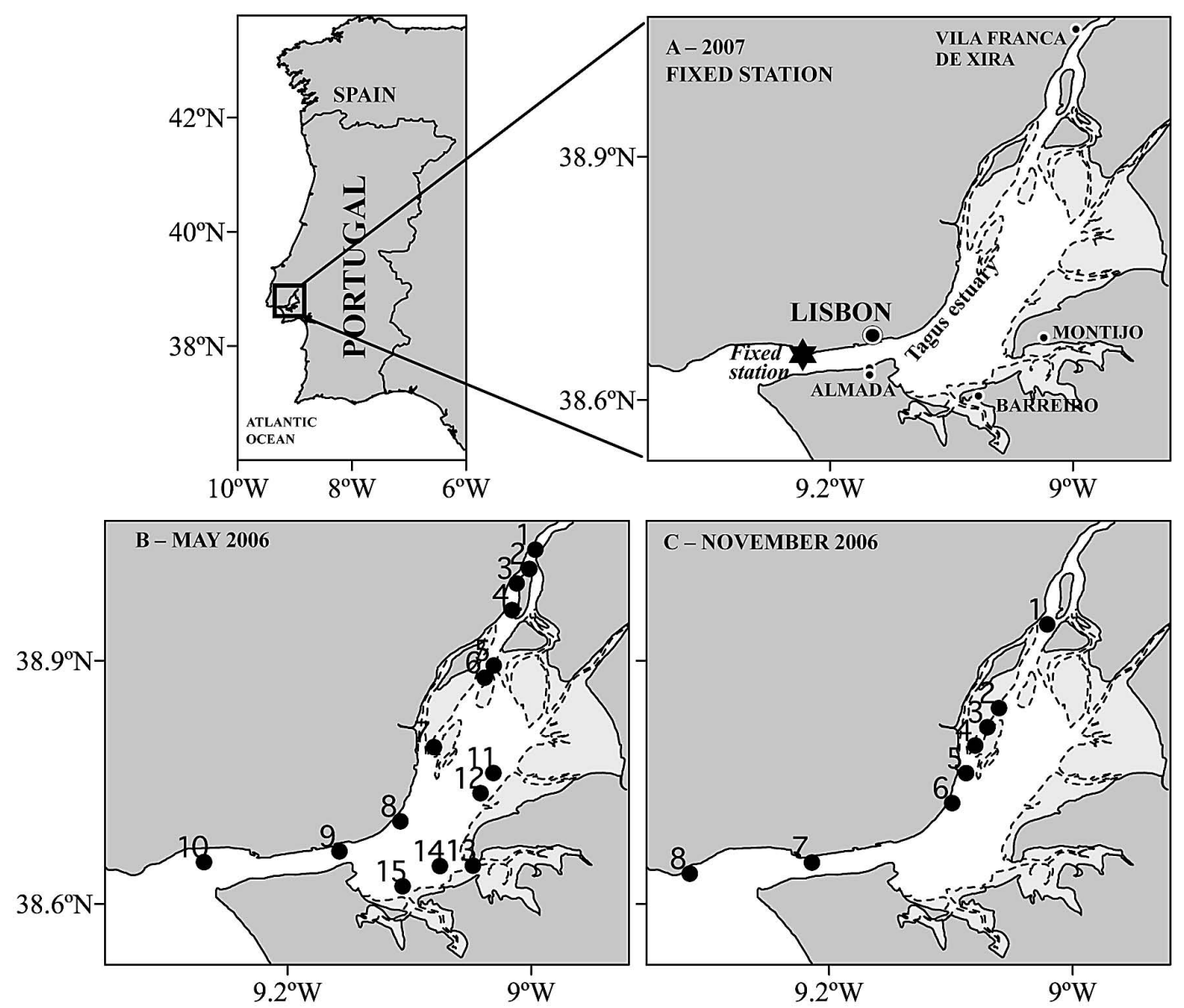

FIG. 1. - Map of Tagus estuary showing the location of sampling sites in A) 2007 (fixed station) ; B) May 2006 and C) November 2006.

advances in research on this biogas, uncertainty still remains concerning $\mathrm{N}_{2} \mathrm{O}$ balances and production and consumption mechanisms (IPCC, 2001). The ocean's contribution to global emissions of atmospheric $\mathrm{N}_{2} \mathrm{O}$ was estimated to be about $30 \%$, of which $60 \%$ comes from highly productive regions, such as estuaries and coastal areas (Bange et al., 1996; Seitzinger et al., 2000). The production of $\mathrm{N}_{2} \mathrm{O}$ is linked to the microbial turnover of inorganic nitrogen by nitrifying and denitrifying organisms (Ritchie and Nicholas, 1972; Poth and Focht, 1985; Wrage et al., 2001). During nitrification, the aerobic two-step process in which ammonium is oxidized to nitrate $\mathrm{N}_{2} \mathrm{O}$ is assumed to be a by-product, although the exact metabolism is still under discussion (Ostrom et al., 2000). In suboxic habitats, nitrate can be reduced by denitrification to molecular nitrogen, with $\mathrm{N}_{2} \mathrm{O}$ as an intermediate (Cohen and Gordon, 1978).

As $\mathrm{N}_{2} \mathrm{O}$ production depends strongly on environmental conditions (Naqvi et al., 2000), any natural or anthropogenic-induced shifts in the aquatic system will affect the formation and subsequent release of $\mathrm{N}_{2} \mathrm{O}$ to the atmosphere. Nitrogen load is a main factor controlling $\mathrm{N}_{2} \mathrm{O}$ emissions from estuarine sediments (Seitzinger and Nixon, 1985; Middelburg et al., 1995). Seitzinger et al. (2000) and Cabrita and Brotas (2000) found denitrification to be an important process of $\mathrm{N}_{2} \mathrm{O}$ formation in intertidal sediments of the Tagus estuary, which receives relatively large inorganic nitrogen inputs from treated and untreated wastewater systems.

Oxygen is known to be another key factor controlling both $\mathrm{N}_{2} \mathrm{O}$ production in aquatic ecosystems and the temporal variability of ammonium. It is therefore important to understand the main factors regulating the production and variability of $\mathrm{N}_{2} \mathrm{O}$ within individual systems. In the present work we study the seasonal and tidal variability of $\mathrm{N}_{2} \mathrm{O}$ levels and fluxes, and their relationship with inorganic nitrogen species and other environmental variables in the Tagus estuary.

\section{MATERIALS AND METHODS}

\section{Description of the study area}

The Tagus estuary, one of the largest in Western Europe, is located in the most populated area of Portugal that includes the capital, Lisbon (Fig. 1), and occupies an area of about $320 \mathrm{~km}^{2}$ (Ferreira et al., 2003). The main freshwater source to the estuary is the River Tagus, which produces an annual mean discharge of approximately $400 \mathrm{~m}^{3} \mathrm{~s}^{-1}$ (Bettencourt et al., 2003). 
TABLE 1. - Surface temperature (T), Tidal amplitude, river flow rate (Q) and wind speed (U10), along the Tagus estuary (May and November 2006) and at the fixed station during tidal cycles (February and April 2007).

\begin{tabular}{cccccc}
\hline Date & & Tide & $\begin{array}{c}\text { Tidal } \\
\text { amplitude }(\mathrm{m})\end{array}$ & $\begin{array}{c}\mathrm{Q}^{\mathrm{a}} \\
\left(\mathrm{m}^{3} \mathrm{~s}^{-1}\right)\end{array}$ & $\begin{array}{c}\mathrm{U}_{10}^{\mathrm{b}} \\
\left(\mathrm{m} \mathrm{s}^{-1}\right)\end{array}$ \\
\hline 2006 & $\begin{array}{c}\text { May } \\
\text { November }\end{array}$ & $\begin{array}{c}\text { ebb } \\
\text { ebb }\end{array}$ & ---- & 46 & $1.8-7.9$ \\
2007 & February & neap & $1.4-2.7$ & 768 & $0.9-3.5$ \\
& & spring & $0.6-3.8$ & 34 & $6.1-8.0$ \\
& April & neap & $1.4-3.0$ & 24 & $0.2-6.6$ \\
& & spring & $0.3-4.2$ & 15 & $3.7-6.6$ \\
\hline
\end{tabular}

${ }^{a}$ Monthly mean flow rate (SNIRH, 2007; http://www.snirh.pt)

${ }^{\mathrm{b}}$ Mean wind velocity (10 min average) at the observation site.

There is a pronounced dry/wet season discharge signal $\left(\sim 30 \mathrm{~m}^{3} \mathrm{~s}^{-1}\right.$ in a dry summer and $2000 \mathrm{~m}^{3} \mathrm{~s}^{-1}$ in a wet winter) (SNIRH, 2006), so the residence time of freshwater in the estuary is highly variable, ranging from approximately 6 to 65 days (Martins et al., 1984). Though organic loadings to the estuary have been reduced in recent years, partially treated or untreated effluents from greater Lisbon, particularly from the southern shoreline, still contribute approximately $30 \%$ of total organic nitrogen and $10 \%$ of nitrate (IST/ Maretec, 2002). Diffuse nutrient loads due to the leaching of agricultural land also exist, but they are negligible compared with the contribution of the agricultural load carried by the Tagus river. This mesotidal estuary has three morphologically distinct regions corresponding to different habitats: the upstream, middle and downstream sections (Brogueira and Cabeçadas, 2006). The large and shallow upper part of the estuary has an average depth of $2 \mathrm{~m}$ and includes extensive mudflats and salt marshes, the middle part is deeper and has an average depth of $7 \mathrm{~m}$, and the lower part has maximum depths of $46 \mathrm{~m}$. The combined effects of relatively shallow depths and strong tidal currents make the Tagus estuary a generally well-mixed system. Tides are semi-diurnal with amplitudes ranging from about $1 \mathrm{~m}$ at neap tides to about $4 \mathrm{~m}$ at spring tides. The Tagus estuary shows an asymmetric behaviour of flood and ebb, which leads to stronger velocities during ebbs (Fortunato et al., 1999). The wind also plays an important role in estuarine circulation, blowing predominantly from south and southwest in winter, rotating progressively to the northwest and north in spring and maintaining this direction in summer (Braunschweig et al., 2003).

\section{Sampling and analytical methods}

Surface water (0.2 m depth) samples (duplicate) were collected along the salinity gradient, during ebb, in May and in November 2006, corresponding to low and high water river flow, $46 \mathrm{~m}^{3} \mathrm{~s}^{-1}$ and $768 \mathrm{~m}^{3} \mathrm{~s}^{-1}$, respectively (SNIRH, 2007). In May, sampling was carried out all along the estuary, including the Barreiro/ Montijo area (Fig. 1B), while in November samples were taken along a main transect following the right bank, as shown in Figure 1C.

In 2007, sampling was performed at a fixed site $\left(38.8^{\circ} \mathrm{N}, 9.2^{\circ} \mathrm{W}\right)$ (Fig. 1A) during February and April at spring and neap tides. Surface water samples (triplicate) were taken every hour covering one tidal cycle (approximately $13 \mathrm{~h}$ ). Sampling dates, tidal conditions, Tagus river flow and wind speed are detailed in Table 1.

Water samples for analysis of physical (salinity) and chemical parameters (dissolved nitrate, nitrite, ammonium, oxygen and nitrous oxide) and chlorophyll $a$ were collected with 2-L Niskin bottles.

Salinity (S) measurements were carried out using a temperature-controlled conductive salinometer (Guideline). Temperature (T) was determined in situ with an Aanderaa probe (CTD sensor). Meteorological parameters were measured using a portable meteorological station (Campbell Scientific CR 510). Measured wind speeds were converted to wind at $10 \mathrm{~m}\left(\mathrm{U}_{10}\right)$ using a logarithmic correction (Pond, 1975; Hartman and Hamond, 1985). Monthly means of the Tagus river outflow at the hydrometric station in Almourol $\left(39.8^{\circ} \mathrm{N}\right.$, $8.4^{\circ} \mathrm{W}$ ), located upstream of the Tagus estuary, were obtained from SNIRH (2007) and are available online at www.snirh.pt.

Dissolved oxygen (referred herein as $\mathrm{O}_{2}$ ) was determined according to the Winkler method, as described by Aminot and Chaussepied (1983). The precision of this method was between $0.08 \%$ and $0.25 \%$.

Water samples for determination of dissolved nutrients were filtered through acetate cellulose filters (pore size $0.45 \mu \mathrm{m}$ ) and frozen until analysis. Nutrient analyses were carried out using a TRAACS autoanalyzer following colorimetric techniques outlined by the manufacturer. Estimated precision (10 replicates) is as follows: $\pm 2.6 \%$ for nitrate and nitrite (referred to as $\mathrm{NO}_{3}{ }^{-}$and $\mathrm{NO}_{2}^{-}$, respectively) and $\pm 2.0 \%$ for ammonium (referred to as $\mathrm{NH}_{4}^{+}$), at mid-scale concentrations. Accuracy of nutrient measurements was maintained by using CSK Standards (WAKO, Japan).

For determination of nitrous oxide $\left(\mathrm{N}_{2} \mathrm{O}\right)$, bubble free sub-samples were taken (three replicates) into 20-ml glass vials, immediately poisoned with $40 \mu \mathrm{l}$ of saturated aqueous mercury chloride $\left(\mathrm{HgCl}_{2}\right)$ to prevent microbial activity, and sealed with gastight caps. The vials were stored upside down, in the dark, at $4^{\circ} \mathrm{C}$ and analyzed within 10 days after collection. Dissolved $\mathrm{N}_{2} \mathrm{O}$ concentration was determined by gas chromatography using a GC - ECD (GC Varian CP3800) headspace technique. In this procedure $5 \mathrm{ml}$ of the sample were replaced by helium and equilibrium was performed in a headspace CombiPAL autosampler. Gas chromatographic separation was carried out using a stainless steel column packed with 80/100 (mesh) Porapak and detected by a ${ }^{63} \mathrm{Ni}$ electron capture detector (ECD). Calibration of ECD response was done using standard $\mathrm{N}_{2} \mathrm{O}$ gas mixtures in synthetic air (Air Líquide) and the precision of the method was $3 \%$. $\mathrm{N}_{2} \mathrm{O}$ concentrations in the water samples were calculated from the concentrations meas- 


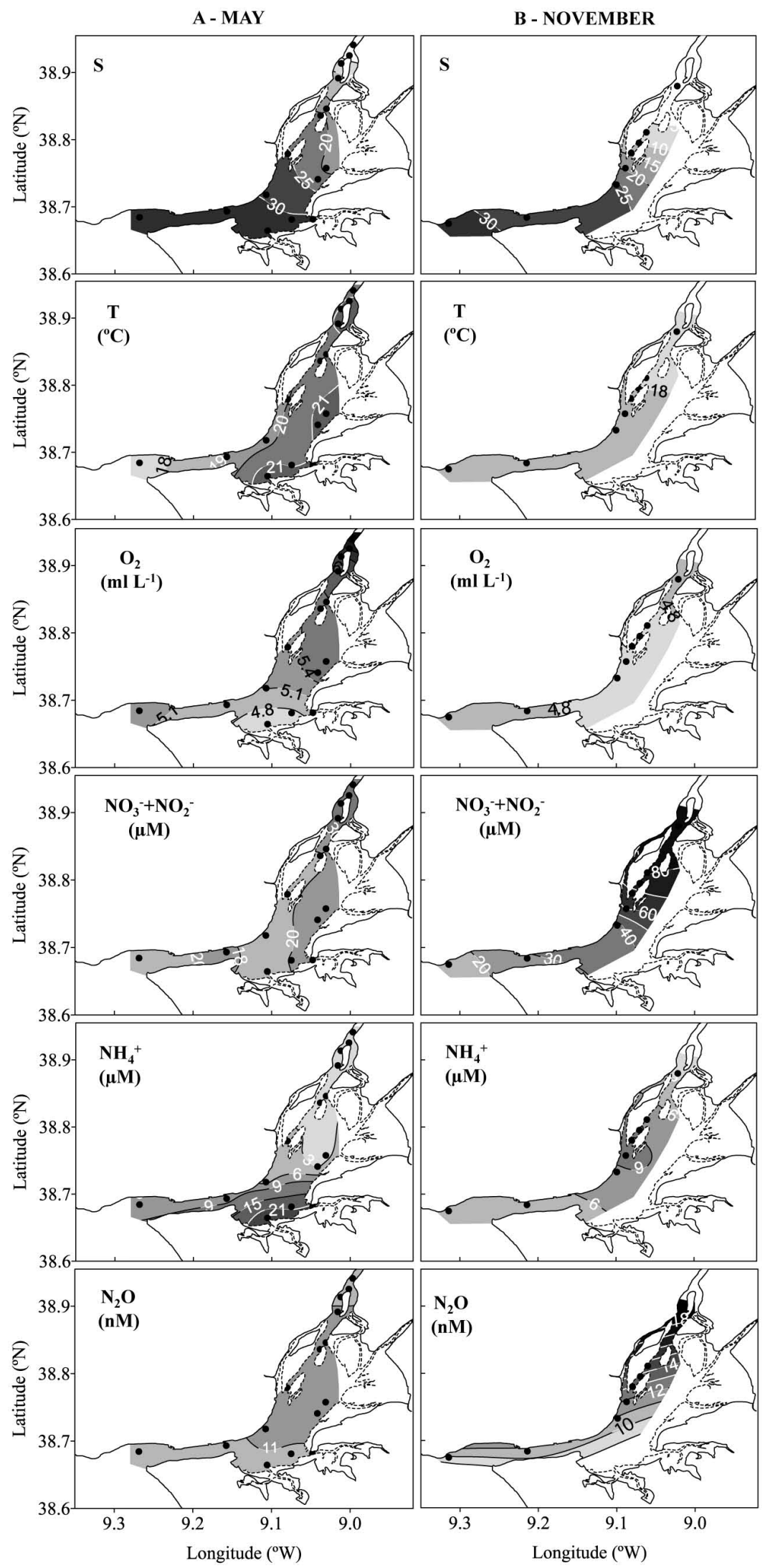

FIG. 2. - Spatial distribution of physical (Salinity (S) and Temperature (T)) and chemical parameters (dissolved oxygen $\left(\mathrm{O}_{2}\right)$, nutrients $\left(\mathrm{NO}_{3}{ }^{-}\right.$ $\left.+\mathrm{NO}_{2}^{-}, \mathrm{NH}_{4}^{+}\right)$and nitrous oxide $\left(\mathrm{N}_{2} \mathrm{O}\right)$ in $(\mathrm{A})$ May and (B) November 2006. 
ured in the headspace according to the solubility equation of Weiss and Price (1980). The equilibrium $\mathrm{N}_{2} \mathrm{O}$ concentrations were calculated from these values and from atmospheric $\mathrm{N}_{2} \mathrm{O}$ concentrations. The $\mathrm{N}_{2} \mathrm{O}$ fluxes across the air-water interface were estimated using the Broecker and Peng (1974) equation and the relation of Clark et al. (1995), since it contains a non-zero intercept, which accounts for gas exchange resulting from tidally induced turbulence in the estuary.

Chlorophyll $a$ (referred to as $\mathrm{Chl} a$ ) was analyzed by fluorometry (Hitachi F-7000 fluorescence spectrophotometer) in $90 \%$ acetone extracts after filtration (Whatman GF/F filters) following Lorenzen's (1967) method. The precision of this method was between $1.5 \%$ and $1.8 \%$.

\section{RESULTS}

\section{Spatial variability}

The spatial distributions of $\mathrm{S}, \mathrm{T}, \mathrm{O}_{2}, \mathrm{NO}_{3}{ }^{-}+\mathrm{NO}_{2}{ }^{-}$, $\mathrm{NH}_{4}{ }^{+}$and $\mathrm{N}_{2} \mathrm{O}$ in May and November 2006 are shown in Figure 2. In November (Fig. 2B), under high Tagus river flow $\left(768 \mathrm{~m}^{3} \mathrm{~s}^{-1}\right)$ salinity values from $\sim 0$ to $\sim 20$ extended to the middle estuary, while in May (Fig. 2A), under low Tagus river flow $\left(46 \mathrm{~m}^{3} \mathrm{~s}^{-1}\right)$, this range was just limited to the upper estuary. Temperature, also differed greatly from November to May, when values higher than $18^{\circ} \mathrm{C}$ were measured all over the main body of the estuary. $\mathrm{O}_{2}$ concentrations were above $4.5 \mathrm{ml}$

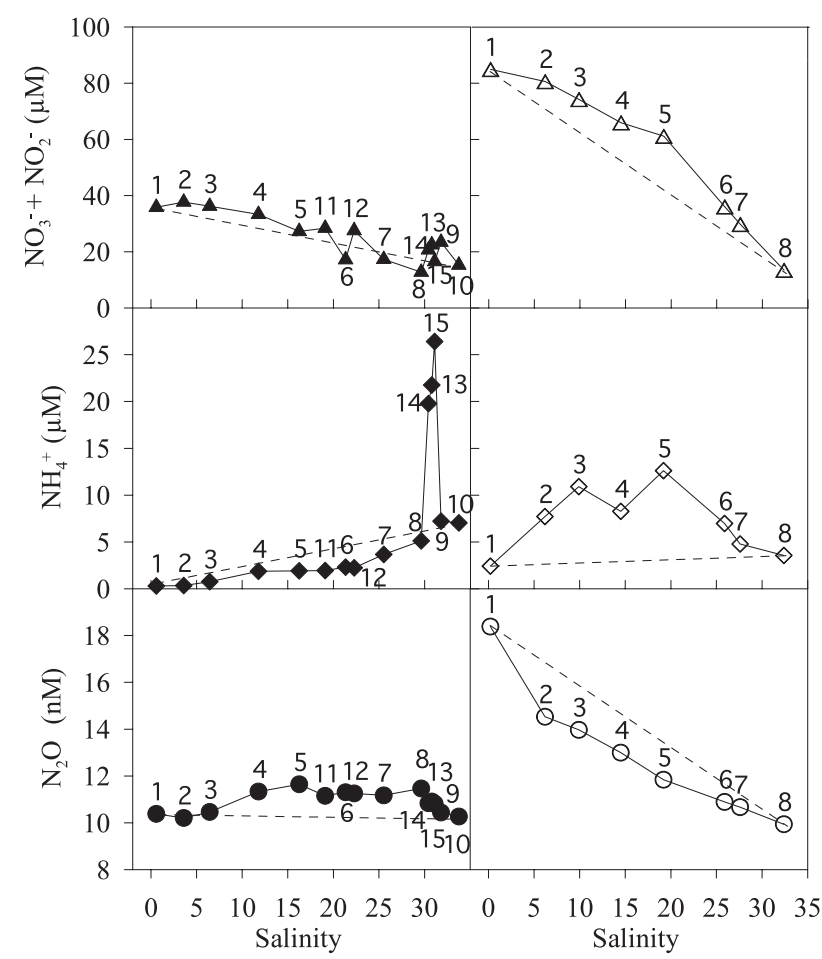

FIG. 3. - Mixing diagrams of nutrients $\left(\mathrm{NO}_{3}^{-}+\mathrm{NO}_{2}^{-}, \mathrm{NH}_{4}^{+}\right)$and nitrous oxide $\left(\mathrm{N}_{2} \mathrm{O}\right)$ in (A) May and (B) November 2006. Numbers correspond to sampling sites according to map in Figure 1.
TABLE 2. - Mean $\mathrm{N}_{2} \mathrm{O}$ concentrations and percent saturation ( \pm standard deviation, $\mathrm{SD}$ ) along the Tagus estuary (May and November 2006) and at the fixed station during tidal cycles (February and April 2007).

\begin{tabular}{lcccc}
\hline \multirow{2}{*}{ Date } & & Tide & $\begin{array}{c}\text { Nitrous Oxide }\left(\mathrm{N}_{2} \mathrm{O}\right) \\
\text { meancentration } \\
(\mathrm{nM})\end{array}$ & $\begin{array}{c}\text { mean saturation } \\
(\%)\end{array}$ \\
\hline 2006 & May & ebb & $10.9 \pm 0.3$ & $132 \pm 2$ \\
& November & ebb & $12.9 \pm 0.1$ & $147 \pm 1$ \\
2007 & February & neap & $11.7 \pm 1.3$ & $125 \pm 14$ \\
& & spring & $12.6 \pm 0.6$ & $135 \pm 6$ \\
& April & neap & $8.7 \pm 0.9$ & $109 \pm 12$ \\
& & spring & $8.3 \pm 0.3$ & $101 \pm 4$ \\
\hline
\end{tabular}

$\mathrm{L}^{-1}$ along the estuary in both periods, and maximum concentrations $\left(7.1 \mathrm{ml} \mathrm{L}^{-1}\right)$ were found in May in the upper estuary, simultaneously with higher chl $a$ levels ( 40 $\mathrm{mg} \mathrm{m}^{-3}$ ) (not shown).

Maximum concentrations of $\mathrm{NO}_{3}{ }^{-}+\mathrm{NO}_{2}{ }^{-}$were observed in the upper estuary (Fig. 2) in November ( 85 $\mu \mathrm{M})$ and in May $(\sim 38 \mu \mathrm{M})$, indicating the major input from Tagus river. The existence of local inputs along the system is perceptible through the mixing diagrams (Fig. 3), which show the non-conservative behaviour of this nutrient in both sampling periods. The highest concentrations of $\mathrm{NH}_{4}^{+}$were observed in May (Fig. 2A) when a gradual increase was observed from the upper to the lower estuary. In the vicinity of Barreiro/ Montijo (stations 13, 14 and 15), $\mathrm{NH}_{4}{ }^{+}$values of up to $26 \mu \mathrm{M}$ were attained simultaneously with lower $\mathrm{O}_{2}$ values (4.6 ml L-1). The mixing diagrams (Fig. 3) show the non-conservative behaviour of $\mathrm{NH}_{4}^{+}$in both sampling periods, with the system acting as an $\mathrm{NH}_{4}{ }^{+}$sink in May (Fig. 3A) except for the mentioned area (stations 13, 14, 15) and as an $\mathrm{NH}_{4}{ }^{+}$source in November (Fig. 3B).

Regarding the $\mathrm{N}_{2} \mathrm{O}$ distributions, higher values were observed in November (Fig. 2B) in the upper estuary, where values of up to $\sim 18.0 \mathrm{nM}$ were attained, decreasing towards the lower estuary. Apparently, the River Tagus river was also the main $\mathrm{N}_{2} \mathrm{O}$ source in this high river flow period. Further, the concave curve of the $\mathrm{N}_{2} \mathrm{O}$ profile along salinity (Fig. 3B) indicates that $\mathrm{N}_{2} \mathrm{O}$ in the estuary decreases faster than would be expected from conservative mixing with the $\mathrm{N}_{2} \mathrm{O}$-poor coastal water. In May $\mathrm{N}_{2} \mathrm{O}$ concentrations varied only between $10.2 \mathrm{nM}$ and $12.6 \mathrm{nM}$, with the highest values being observed in the middle estuary (Fig. 2A). In this area, the existence of $\mathrm{N}_{2} \mathrm{O}$ local inputs and/or production is also noticeable through the mixing diagram (Fig. 3A). $\mathrm{N}_{2} \mathrm{O}$ concentrations were above atmospheric equilibrium throughout the entire salinity gradient in both sampling periods (Table 2), indicating that the estuary acts as a potential source of this gas to the atmosphere.

\section{Tidal variability}

Data obtained during tidal cycles are summarized in box plots (Fig. 4). It can be noticed that outliers exist 

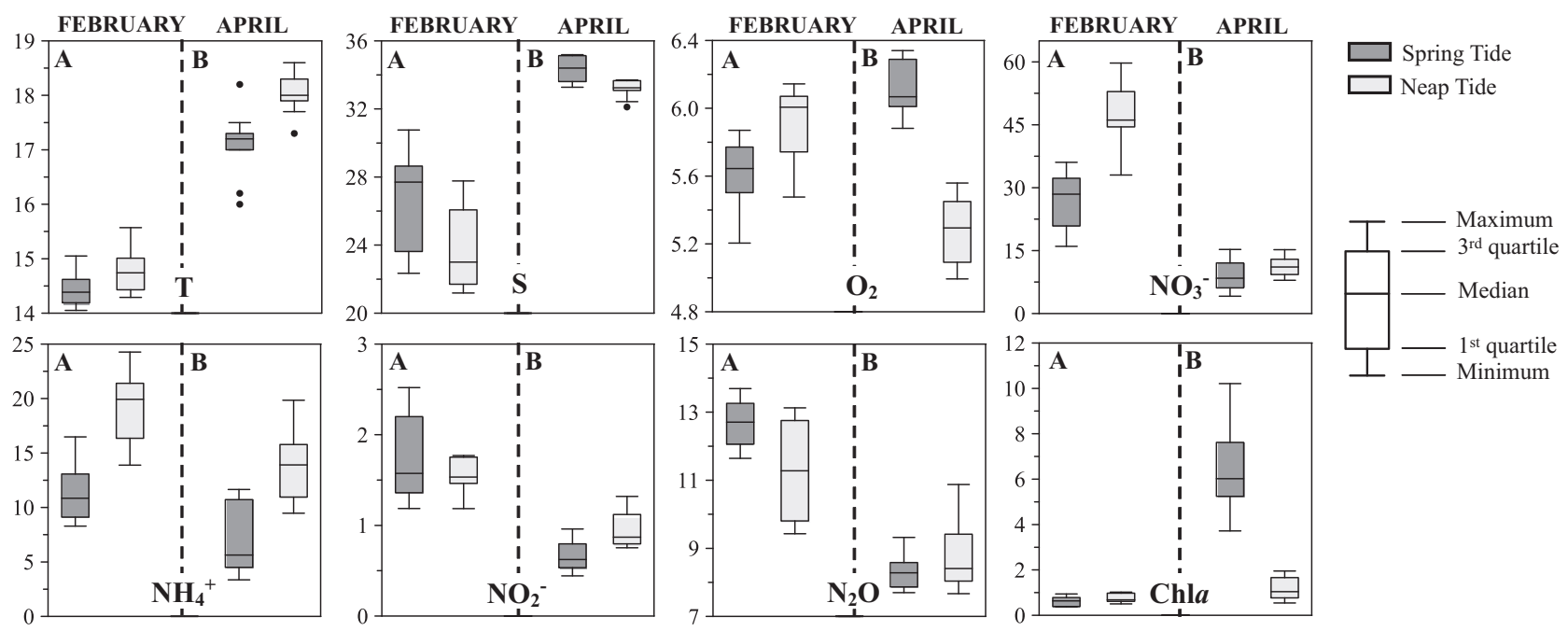

FIG. 4. - Box plots of temperature $(\mathrm{T})\left({ }^{\circ} \mathrm{C}\right)$, salinity $(\mathrm{S})$, dissolved oxygen $\left(\mathrm{O}_{2}\right)\left(\mathrm{ml} \mathrm{L}^{-1}\right)$, nutrients $\left(\mathrm{NO}_{3}^{-}, \mathrm{NH}_{4}^{+}, \mathrm{NO}_{2}^{-}\right)(\mu \mathrm{M})$, nitrous oxide $\left(\mathrm{N}_{2} \mathrm{O}\right)(\mathrm{nM})$ and Chlorophyll $a(\mathrm{Chl} a)\left(\mathrm{mg} \mathrm{m}^{-3}\right)$ in (A) February and (B) April 2007, during spring and neap tide.

only in April for T, at both spring and neap tides and for $\mathrm{S}$, at neap tide. $\mathrm{S}, \mathrm{NO}_{3}{ }^{-}$and $\mathrm{N}_{2} \mathrm{O}$ exhibited a larger spread in February, while the reverse was true for Chl $a$ which had much lower values in February. Variables T, $\mathrm{S}, \mathrm{NO}_{3}^{-}, \mathrm{NO}_{2}^{-}$and $\mathrm{N}_{2} \mathrm{O}$ as well, exhibit a good separation between February and April. S, dissolved nutrients $\left(\mathrm{NO}_{3}^{-}, \mathrm{NO}_{2}^{-}\right.$and $\left.\mathrm{NH}_{4}^{+}\right), \mathrm{N}_{2} \mathrm{O}$ and $\mathrm{Chl} a$ revealed a typical seasonal variability. Higher T, S and $\mathrm{Chl} a$ values were attained in April, while dissolved nutrients and $\mathrm{N}_{2} \mathrm{O}$ showed higher values in February, when higher external nutrient loading occurred. Furthermore, in February $\mathrm{NO}_{3}^{-}, \mathrm{NH}_{4}{ }^{+}$and $\mathrm{N}_{2} \mathrm{O}$ exhibited a good distinction between neap and spring tides. In April a separation between tides is also seen in $\mathrm{O}_{2}, \mathrm{NH}_{4}{ }^{+}$and $\mathrm{Chl}$ $a$. Trends of $\mathrm{N}_{2} \mathrm{O}$ are compared with those of the most relevant parameters assumed to be directly connected with the production pathways of this biogas $\left(\mathrm{NH}_{4}^{+}\right.$, $\mathrm{O}_{2}, \mathrm{NO}_{2}^{-}$) (Figs. 5, 6). In February during spring tide (Fig. $5 \mathrm{~A}$ ), when higher levels of $\mathrm{N}_{2} \mathrm{O}$ were detected, the simultaneous rise in $\mathrm{N}_{2} \mathrm{O}$ and $\mathrm{NO}_{2}{ }^{-}$concentrations and the fall in $\mathrm{NH}_{4}{ }^{+}$and $\mathrm{O}_{2}$ concentrations occurred at slack water, both at low tide (LT) and at high tide (HT). Negative correlations were found between $\mathrm{N}_{2} \mathrm{O}$ and $\mathrm{NH}_{4}{ }^{+}\left(\mathrm{N}=6, \mathrm{R}^{2}=0.80, P<0.02\right)$ and between $\mathrm{N}_{2} \mathrm{O}$ and $\mathrm{O}_{2}\left(\mathrm{~N}=5, \mathrm{R}^{2}=0.80, P<0.04\right)$, which suggests in situ $\mathrm{N}_{2} \mathrm{O}$ production through the nitrification process. At neap tide (Fig. 5B), the increase in $\mathrm{N}_{2} \mathrm{O}$ concentrations also detected near slack water (HT) was, however, accompanied by simultaneous increases in $\mathrm{NH}_{4}^{+}, \mathrm{O}_{2}$ and $\mathrm{NO}_{2}^{-}$, which does not suggest the occurrence of nitrification under this tidal condition. In April, $\mathrm{N}_{2} \mathrm{O}$ variability was also much lower during spring tide (Fig. 6A) than at neap tide (Fig. 6B), although higher $\mathrm{N}_{2} \mathrm{O}$ values were also observed at slack water (either at HT or at LT). Surface waters were always supersaturated with $\mathrm{N}_{2} \mathrm{O}$ and a maximum mean $\mathrm{N}_{2} \mathrm{O}$ saturation value of $135 \%$ was attained in February during spring tide (Table 2).

\section{Air-sea $\mathrm{N}_{2} \mathrm{O}$ fluxes}

$\mathrm{N}_{2} \mathrm{O}$ air-sea fluxes estimated in the Tagus estuary in May and November 2006 are shown in Figure 7. Similar patterns were observed along the right bank of the estuary (St. 1 to St. 10/St. 8, in May/November, respectively) in both sampling periods, with a progressive decrease towards the lower estuary. The highest $\mathrm{N}_{2} \mathrm{O}$ air-sea fluxes $\left(10.4 \mu \mathrm{mol} \mathrm{m} \mathrm{m}^{-2} \mathrm{~d}^{-1}\right)$ were observed in May (Fig. 7A) in both the upper and lower (left bank) estuary, when wind speed attained the maximum values $\left(\sim 8 \mathrm{~m} \mathrm{~s}^{-1}\right)$. In November (Fig. 7B), under lower wind speeds $\left(\leq 3.5 \mathrm{~m} \mathrm{~s}^{-1}\right), \mathrm{N}_{2} \mathrm{O}$ air-sea fluxes varied only between 1.5 and $6.8 \mu \mathrm{mol} \mathrm{m}^{-2} \mathrm{~d}^{-1}$, despite the highest $\mathrm{N}_{2} \mathrm{O}$ concentration measured in the upper estuary. Fluxes compare with those calculated from intertidal sediments of the lower Tagus estuary by Cabrita and Brotas (2000), who also detected seasonal variability.

$\mathrm{N}_{2} \mathrm{O}$ air-sea fluxes estimated during tidal cycles in February and April 2007 are shown in Figure 8. Much higher $\mathrm{N}_{2} \mathrm{O}$ exchange values were recorded in February during spring tide, when higher $\mathrm{N}_{2} \mathrm{O}$ concentrations and simultaneous high river runoff and wind speeds were recorded. At spring tide a progressive increase in $\mathrm{N}_{2} \mathrm{O}$ flux was estimated during the flood and a maximum value of $10.4 \mu \mathrm{mol} \mathrm{m} \mathrm{m}^{-2} \mathrm{~d}^{-1}$ was reached. At neap tide values did not exceed $4.1 \mu \mathrm{mol} \mathrm{m}^{-2} \mathrm{~d}^{-1}$ and the variability of $\mathrm{N}_{2} \mathrm{O}$ fluxes during the tidal cycle was not so pronounced. In April during spring tide, much lower and even some negative fluxes were estimated. During the neap tidal cycle, wind speed never exceeded $0.6 \mathrm{~m} \mathrm{~s}^{-1}$ and estimated fluxes were always positive though they did not exceed $1.2 \mu \mathrm{mol} \mathrm{m}{ }^{-2} \mathrm{~d}^{-1}$.

\section{DISCUSSION}

Our results provide evidence of pronounced seasonal and tidal variability of $\mathrm{N}_{2} \mathrm{O}$ levels in the Tagus 


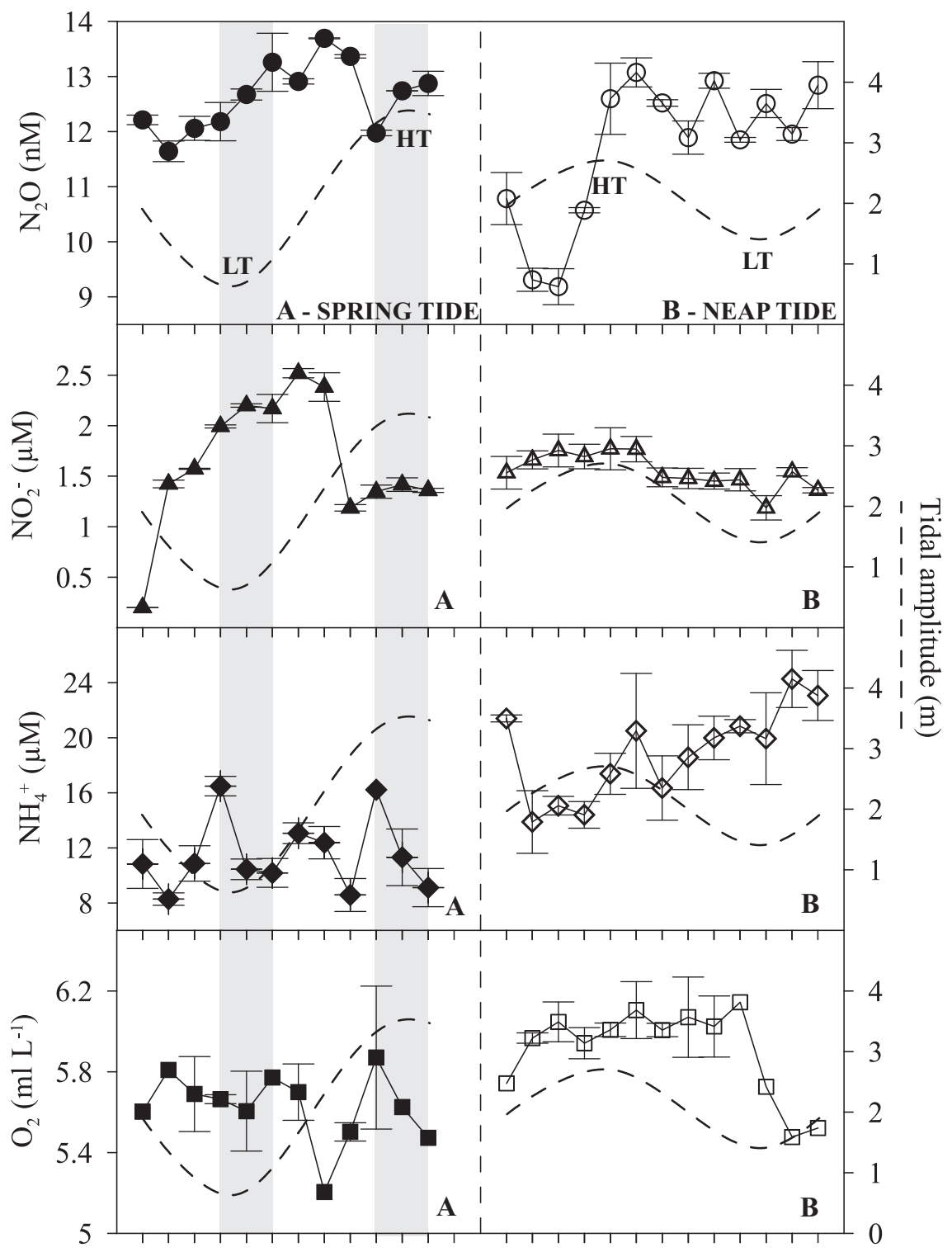

012345678910111200123456789101112

Time (h)

Time (h)

FIG. 5. - Variability of dissolved nitrous oxide $\left(\mathrm{N}_{2} \mathrm{O}\right)$, nutrients $\left(\mathrm{NO}_{2}^{-}, \mathrm{NH}_{4}^{+}\right)$and oxygen $\left(\mathrm{O}_{2}\right)$ in February 2007 during (A) spring tide and (B) neap tide (HT - High Tide; LT - Low Tide) (Error bars $= \pm 1 \mathrm{SD}$ ).

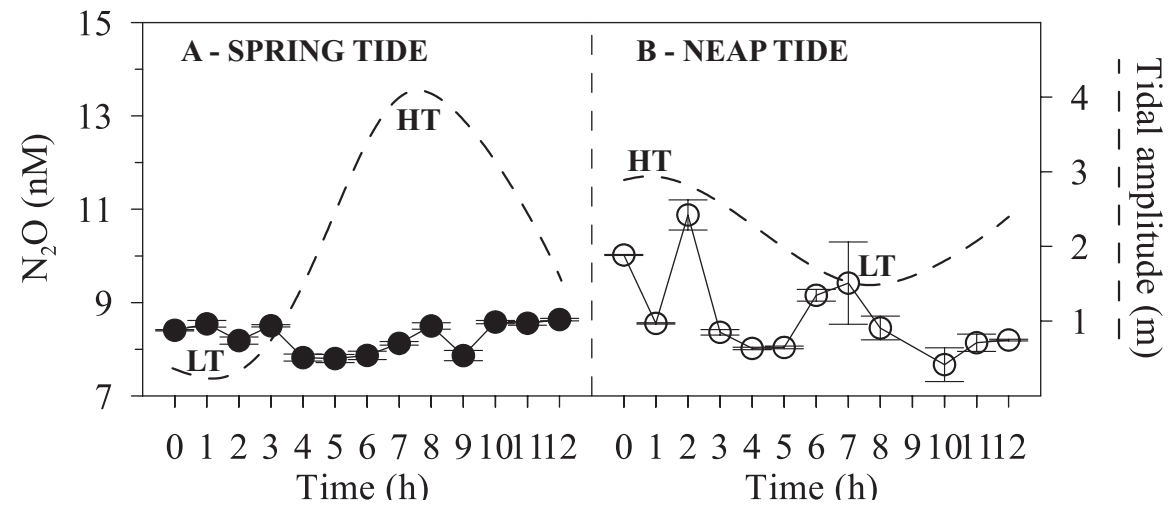

FIG. 6. - Variability of dissolved nitrous oxide $\left(\mathrm{N}_{2} \mathrm{O}\right)$ in April 2007 during (A) spring tide and (B) neap tide (Error bars $= \pm 1 \mathrm{SD}$ ). 


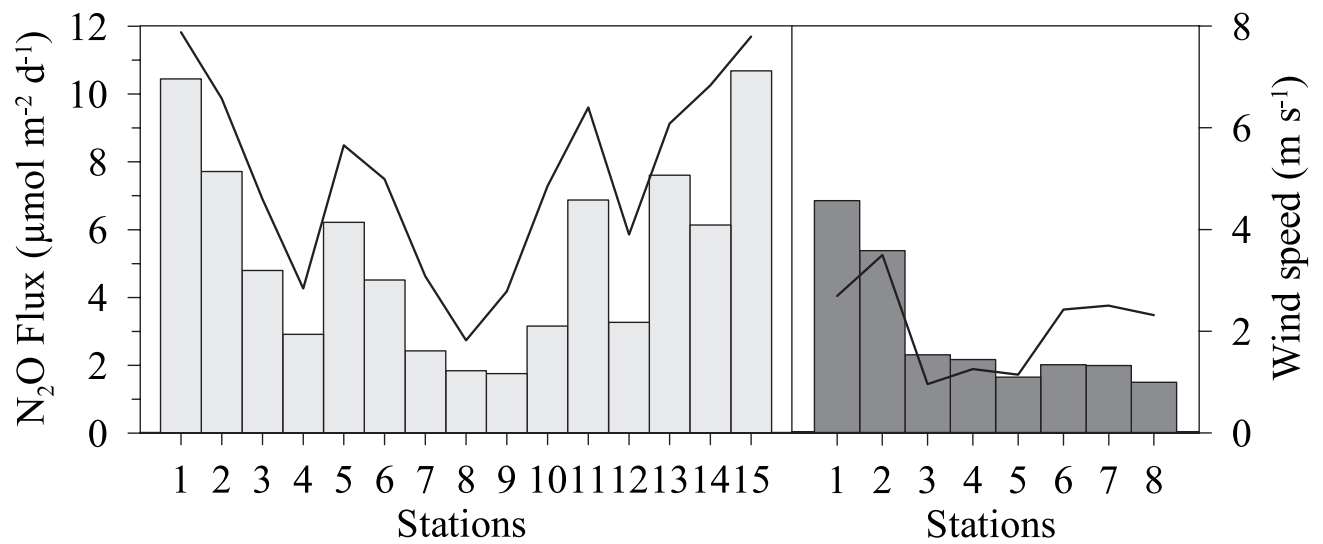

FIG. 7. - Air-sea $\mathrm{N}_{2} \mathrm{O}$ fluxes (bar charts) in (A) May and (B) November 2006. Wind speed is represented by solid lines. The river flow (Q) is also indicated.
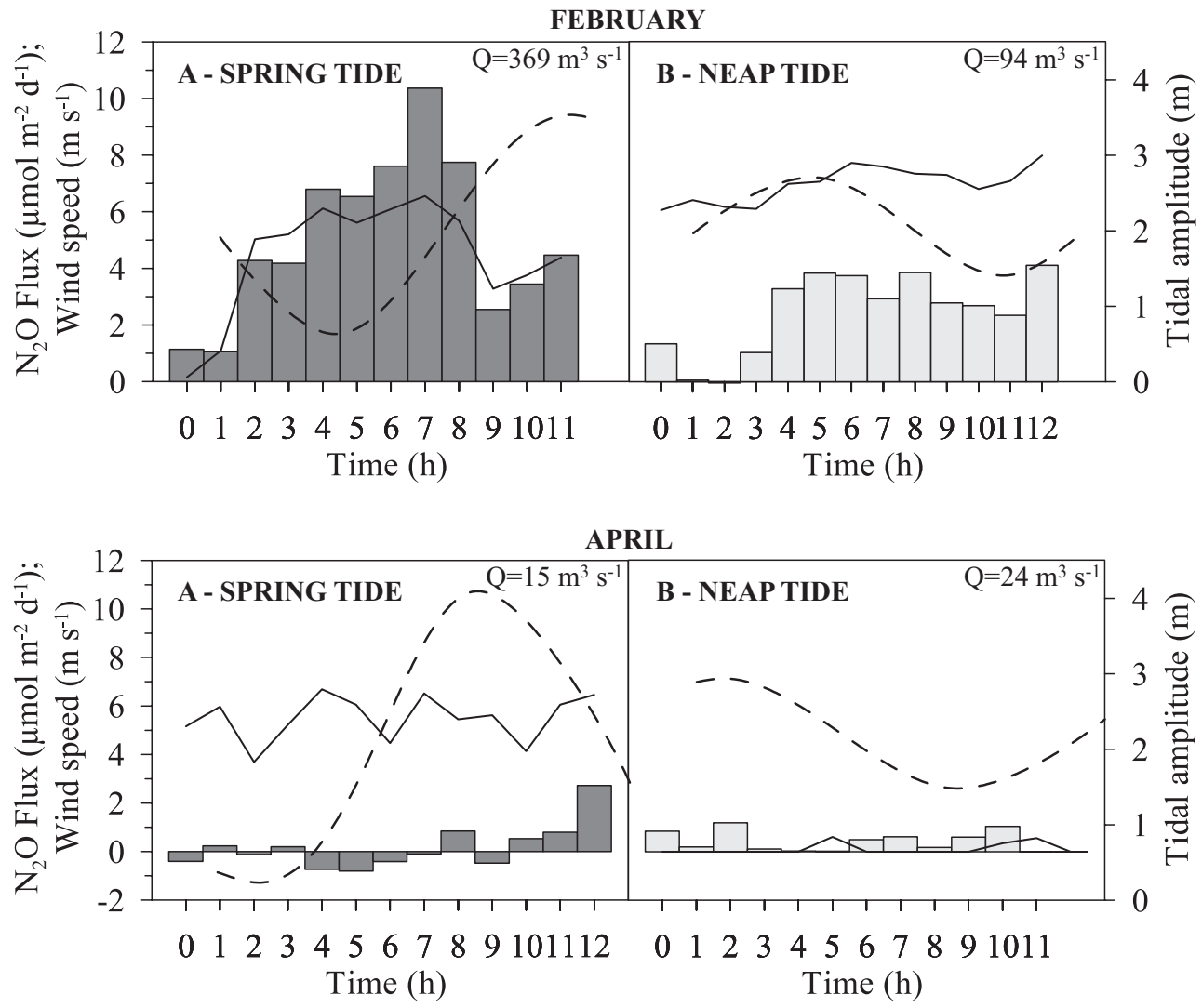

Spring tide

Neap tide

FIG. 8. - Air-sea $\mathrm{N}_{2} \mathrm{O}$ fluxes (bar charts) in February and April 2007 during (A) spring tide and (B) neap tide. Wind speed is represented by solid lines and tidal amplitude by dotted lines. The river flow $(\mathrm{Q})$ is also indicated.

estuary, although the values obtained along the salinity gradient were of the same order of magnitude as those obtained during tidal cycles. The highest absolute and percent saturation $\mathrm{N}_{2} \mathrm{O}$ values in the water column occurred in autumn (November 2006)/winter (February 2007), apparently associated with a major Tagus river discharge observed in these periods. Lower water temperatures may also have favoured higher $\mathrm{N}_{2} \mathrm{O}$ solubility in water in autumn/winter. The non-conservative
$\mathrm{N}_{2} \mathrm{O}$ behaviour along the estuary indicates that the middle estuary was acting as a sink. As the entire Tagus estuary is well oxygenated $\left(>4.5 \mathrm{ml} \mathrm{L}^{-1}\right)$, the $\mathrm{N}_{2} \mathrm{O}$ decrease seems to result mainly from gas emission to the atmosphere, as it is unlikely that $\mathrm{N}_{2} \mathrm{O}$ is consumed at oxygen concentrations above $2 \mu \mathrm{mol} \mathrm{dm}{ }^{-3}$ (Codispoti and Christensen, 1985). During spring (May 2006), when the River Tagus flow was more reduced, $\mathrm{N}_{2} \mathrm{O}$ concentrations were much lower, even in the upper es- 
tuary. Nevertheless, internal sources/production were apparently acting in the middle/lower estuary. From relevant parameters connected with the production of $\mathrm{N}_{2} \mathrm{O}$, the occurrence of nitrification could not be deduced. Other additional $\mathrm{N}_{2} \mathrm{O}$ sources are probably influencing $\mathrm{N}_{2} \mathrm{O}$ production in the estuary. According to Cabrita and Brotas (2000), sediment denitrification in the lower Tagus estuary constitutes an $\mathrm{N}_{2} \mathrm{O}$ source, which may influence $\mathrm{N}_{2} \mathrm{O}$ concentrations in specific areas of this estuary. Furthermore, the existence of inputs from point sources (untreated and partially treated sewage and industrial effluents) in the middle estuary may account for higher $\mathrm{N}_{2} \mathrm{O}$ levels.

$\mathrm{N}_{2} \mathrm{O}$ variability along tidal cycles was consistently higher at neap tides, though maximum values were reached in winter both at spring and neap tides. Apparently, $\mathrm{N}_{2} \mathrm{O}$ production through nitrification may represent an additional $\mathrm{N}_{2} \mathrm{O}$ source in the estuary. In fact, the correlations found between $\mathrm{N}_{2} \mathrm{O}$ concentrations and $\mathrm{NO}_{2}^{-}$(positive) and $\mathrm{O}_{2}$ and $\mathrm{NH}_{4}^{+}$(negative) close to slack water can be interpreted as resulting from in situ $\mathrm{N}_{2} \mathrm{O}$ production by nitrification, probably favoured by larger amounts of particles during spring tides and higher residence time. This process, whose primary substrate $\mathrm{NH}_{4}{ }^{+}$maintained relatively high levels in the estuary in winter, is likely favoured by the presence of a larger amount of particles and higher residence time at slack water. It is known that most nitrifiers are attached to particles (Stehr et al., 1995) and their accumulation contributes to the enhancement of nitrifying population growth and nitrifying action in many estuaries (Abril et al., 2000; Brion et al., 2000). Also, near slack water less atmospheric exchange favours the enhancement of $\mathrm{N}_{2} \mathrm{O}$ levels in seawater.

Similarly to fluctuation in $\mathrm{N}_{2} \mathrm{O}$ levels, $\mathrm{N}_{2} \mathrm{O}$ fluxes in the Tagus estuary varied seasonally, along the salinity gradient, and also with the tidal state. The highest $\mathrm{N}_{2} \mathrm{O}$ air-sea fluxes along the estuary (10.4 $\mu \mathrm{mol} \mathrm{m} \mathrm{m}^{-2} \mathrm{~d}^{-1}$ ) were measured in May in the upper and lower (left bank) estuary, despite the higher $\mathrm{N}_{2} \mathrm{O}$ levels found in November. The rate of gas exchange with the atmosphere is largely determined by wind speed (Liss and Merlivat, 1986; Wanninkhof, 1992) and approximately proportional to the square of the wind speed (Clark et al., 1995). Actually, wind speed recorded in May was $8 \mathrm{~m} \mathrm{~s}^{-1}$ while in November it did not exceed $3.5 \mathrm{~m} \mathrm{~s}^{-1}$.

In relation to $\mathrm{N}_{2} \mathrm{O}$ emissions during tidal cycles, the enhancement of $\mathrm{N}_{2} \mathrm{O}$ fluxes at spring tide, during flood, observed in February seems to be caused not only by wind stress, but also by strong water turbulence induced by simultaneous effects of tidal force and higher river flow. Although this estuary behaves predominantly as a source of atmospheric $\mathrm{N}_{2} \mathrm{O}$, in particular during the winter period, fluxes are low and the area may even function as a potential sink of atmospheric $\mathrm{N}_{2} \mathrm{O}$ at times, suggesting that this system is a weaker source of atmospheric $\mathrm{N}_{2} \mathrm{O}$ than other more eutrophic estuaries.

\section{ACKNOWLEDGEMENTS}

The authors wish to thank our colleagues A.P. Oliveira and C. Araújo for help in field sample collection and laboratory analysis. The research was supported by the PoPesca MARE project (22-05-01-FDR) and by the FCT-Portuguese Foundation of Science and Technology (POCI 2010 and FSE) through grant SFRH/BD/28569/2006. We thank to the anonymous reviewers for helpful suggestions that improved the manuscript.

\section{REFERENCES}

Abril, G., S.A. Riou, H. Etcheber, M. Frankignoulle, R. De wit and J.J. Middelburg. - 2000. Transient, Tidal Time-scale, Nitrogen Transformations in an Estuarine Turbidity Maximum-Fluid Mud System (The Gironde, South-West France). Est. Coast. Shelf Sci., 50(5): 703-715.

Aminot, A. and M. Chaussepied. - 1983. Manuel des analyses chimiques en milieu marin, 395 p. Centre National pour l'Exploitation des Océans (CNEXO), Brest, France.

Bange, H.W. - 2006. Nitrous oxide and methane in European coastal waters. Est. Coast. Shelf Sci., 70: 361-374.

Bettencourt, A.M., J.P.G. Ferreira, M.C. Da Silva, J.A. Dias, F.V. Gomes and J.L. Costa. - 2003. Estuários Portugueses. In: Bettencourt, A.M. and L. Ramos (eds.), Estuários e Águas Costeiras, Ecossistemas Aquáticos. PNA-EE: Plano Nacional da Água, 300 pp. INAG, Lisboa.

Braunschweig, F., F. Martins, P. Chambel and R. Neves. - 2003. A methodology to estimate renewal time scale in estuaries: The Tagus Estuary case. Ocean Dynam., 53: 137-145.

Brion, N., G. Bille, L. Guezennec and A. Ficht. - 2000. Distribution of nitrifying activity in the Seine River (France) from Paris to the estuary. Estuaries, 23(5): 669-682.

Broecker, W.S. and T.H. Peng. - 1974. Gas exchange rates between air and sea. Tellus, 26: 21-35.

Brogueira, M.J. and G. Cabeçadas. - 2006. Identification of similar environmental areas in Tagus estuary by using multivariate analysis. Ecol. Ind., 6: 508-515.

Cabrita, M.T. and V. Brotas. - 2000. Seasonal variation in denitrification and dissolved nitrogen fluxes in intertidal sediments of the Tagus estuary, Portugal. Mar. Ecol. Prog. Ser., 202: 51-65.

Clark, J.F., P. Schlosser, H.J. Simpson, M. Stute, R. Wanninkhof and D.T. Ho. - 1995. Relationship between gas transfer velocities and wind speeds in the tidal Hudson River determined by the dual tracer technique. In: Jähne, B. and E. Monahan (eds.), Selected papers from the Third International Symposium on Air-Water gas Transfer, pp. 785-800. AEON Verlag and Studio. Hanau, Germany.

Cicerone, R.J. - 1987. Changes in stratospheric ozone. Science, 337: $35-42$.

Codispoti, K.A. and J.P. Christensen. - 1985. Nitrification, denitrification and nitrous oxide cycling in the eastern tropical South Pacific Ocean. Mar. Chem., 16: 277-300.

Cohen, Y. and L.L. Gordon. - 1978. Nitrous oxide in the minimum of eastern tropical North Pacific: evidence for its consumption during denitrification and possible mechanisms for its production. Deep-Sea Res., 25: 509-524.

Ferreira, J.G., T. Simas, A. Nobre, M.C. Silva, K. Schifferegger and J. Lencart-Silva. - 2003. Identification of Sensitive Areas and Vulnerable Zones in Transitional and Coastal Portuguese Systems. Instituto da Água, INAG/IMAR. ISBN: 972-9412-66-9.

Fortunato, A.B., A. Oliveira and A.M. Baptista. - 1999. On the effect of tidal flats on the hydrodynamics of the Tagus Estuary. Oceanol. Acta, 22(1): 31-44.

Hartman, B. and D.E. Hamond. - 1985. Gas exchange in San Francisco Bay. Hydrobiology, 129: 59-68.

IPCC. - 2001. Climate Change 2001: The Scientific Basis. In: Houghton, J.T., Y. Ding, D.J. Griggs, M. Noguer, P.J. van der Linden, X. Dai, K. Maskell, C.A. Johnson (eds.), Contribution of Working Group I to the Third Assessment Report of the Inter- 
governmental Panel on Climate Change, 881 pp. Cambridge University Press, Cambridge, United Kingdom and New York, NY, USA.

IPCC. - 2007. Climate Change 2007: The Physical Science Basis. In: Solomon, S., D. Qin, M. Manning, Z. Chen, M. Marquis, K.B. Averyt, M. Tignor and H.L. Miller (eds.), Contribution of Working Group I to the Fourth Assessment Report of the Intergovernmental Panel on Climate Change, 996 pp. Cambridge University Press, United Kingdom and New York, NY, USA.

IST/Maretec. - 2002. Water quality in Portuguese estuaries - TejoSado-Mondego. Directivas 91/271/CEE, 91/676/CEE. Instituto da Água, $130 \mathrm{pp}$.

Liss, P.S. and L. Merlivat. - 1986. Air-sea exchange rates: introduction and synthesis. In: Buat-Menard, P. (eds.), The Role of AirSea Exchange in Geochemical Cycling, pp. 113-127. Reidel, Dordrecht.

Lorenzen, C.J. - 1967. Determination of Chlorophyll and Pheopigments: Spectrophotometric Equations. Limnol. Oceanogr., 12: 343-346.

Martins, M., J. Ferreira, T. Calvão and H. Figueiredo. - 1984. Nutrientes no estuário do Tejo-Comparação da situação em caudais médios e em cheia, com destaque para alterações na qualidade da água, 10 pp. I Simpósio Luso-Brasileiro de Engenharia Sanitária e Ambiental.

Middelburg, J.J., G. Klaver, J. Nieuwenhuize, R.M. Markusse, T. Vlug and F.J.W.A. Van der Nat. - 1995. Nitrous oxide emissions from estuarine intertidal sediments. Hydrobiology, 311: 43-45.

Naqvi, S.W.A., D.A. Jayakumar, P.V. Narvekar, H. Naik, V.V.S.S Sarma, W. D'Souza, S. Joseph and M.D. George. - 2000. Increased marine production of $\mathrm{N}_{2} \mathrm{O}$ due to intensifying anoxia on the Indian continental shelf. Nature, 408: 346-349.

Ostrom, N.E., M.E. Russ, B. Popp, T.M. Rust and D.M. Karl. 2000. Mechanisms of nitrous oxide production in the subtropical North Pacific based on determinations of the isotopic abundances of nitrous oxide and di-oxygen. Chemosphere - Global
Change Sci., 2: 281-290.

Pond, S. - 1975. The exchanges of momentum, heat, and moisture at the ocean-atmosphere interface, pp. 26-38. In: Numerical Models of Ocean Circulation. National Academy of Sciences, Washington, D.C.

Poth, M. and D.D. Focht. $-1985 .{ }^{15} \mathrm{~N}$ Kinetic analysis of $\mathrm{N}_{2} \mathrm{O}$ production by Nitrosomonas europaea: an examination of nitrifier denitrification. Appl. Environ. Microbiol., 49(5): 1134-1141.

Ritchie, G.A.F. and D.J. Nicholas. - 1972. Identification of the sources of nitrous oxide produced by oxidative and reductive processes in Nitrosomonas europaea. J. Biochem., 126: 1181-1191.

Seitzinger, S.P. and S.W. Nixon. - 1985. Eutrophication and the rate of denitrification and $\mathrm{N}_{2} \mathrm{O}$ production in coastal marine sediments. Limnol. Oceangr., 30(6): 1331-1339.

Seitzinger, S.P., C. Kroeze and R.V. Styles. - 2000. Global distribution of $\mathrm{N}_{2} \mathrm{O}$ emissions from aquatic systems: natural emissions and anthropogenic effects. Chemosphere-Global Change Sci., 2: $267-279$.

SNIRH - 2006. Sistema Nacional de Informação de Recursos Hídricos. (http://www.snirh.pt)

SNIRH - 2007. Sistema Nacional de Informação de Recursos Hídricos. (http://www.snirh.pt)

Stehr, G., B. Bottcher, P. Dittberner, G. Rath and H.P. Koops. 1995. The ammonia-oxidizing nitrifying population of the River Elbe Estuary. FEMS Microbiol. Ecol., 17(3): 177-186.

Wanninkhof, R. - 1992. Relationship between wind speed and gas exchange over the ocean. J. Geophys. Res., 97: 7373-7382.

Weiss, R.F. and B.A. Price. -1980 . Nitrous oxide solubility in water and seawater. Mar. Chem., 8: 347-359.

Wrage, N., G.L. Vellthof, M.L. van Beusichem and O. Oenema. - 2001. Role of nitrifier denitrification in the production of nitrous oxide. Soil Biol. Biochem., 33(12-13): 1723-1732.

Received November 1, 2008. Accepted July 29, 2010.

Published online November 13, 2010. 